\title{
Budżetowe procedury awaryjne w świetle Konstytucji RP oraz regulacji konstytucyjnych wybranych państw europejskich
}

\section{Budget optional procedures in the light of Constitution of Poland and selected constitutional regulations of Europeans countries}

Streszczenie. W artykule autor porusza problem procedur awaryjnych na wypadek nieuchwalenia ustawy budżetowej. W tym celu dokonuje analizy przepisów Konstytucji RP oraz konstytucji wybranych państw europejskich. Wskazuje na różnice między mechanizmami występującymi w Polsce oraz w wybranych porządkach prawnych. Całość kończy podsumowanie oraz postulaty de lege ferenda.

Słowa kluczowe: ustawa budżetowa; Konstytucja; prowizorium budżetowe; prorogacja.

Abstract. The author raises the problem of optional procedures which are applied when a state budget act is not adopted. The article discusses the problem of the 
constitutional relations between the state budget and provisional budget as well as other optional procedures. Author compares the debt rule which is derived from the Constitution of the Republic of Poland with other similar regulations in other selected European legal orders. The article ends with a summary which contains postulates de lege ferenda.

Keywords: budget law; Constitution; provisional budget; prorogation.

\section{Wprowadzenie}

Regulacje zawarte w Konstytucji Rzeczypospolitej Polskiej z 1997 r. ${ }^{1}$ dążą do jak najszybszego uchwalenia ustawy budżetowej ${ }^{2}$. Najlepiej, jeżeli nastąpi to jeszcze przed rozpoczęciem roku budżetowego, który w polskim porządku prawnym, na mocy przepisów ustawy o finansach publicznych, pokrywa się z rokiem kalendarzowym. Jednakże nie oznacza to, że ustrojodawca wykluczył sytuacje, w których ustawa budżetowa nie została przyjęta lub uchwalona przed rozpoczęciem roku budżetowego.

Ze względu na znaczenie budżetu państwa dla jego prawidłowego funkcjonowania niewyobrażalna jest sytuacja, w której przepisy normujące procedurę budżetową nie uwzględniałyby stosownych procedur awaryjnych. Możliwość wystąpienia niespodziewanych okoliczności, wpływających na przebieg procesu budżetowego i opóźniających go implikuje potrzebę wprowadzenia rozwiązań przejściowych, które ze względu na swoją doniosłość powinny zostać unormowane w przepisach rangi konstytucyjnej, choć nie zawsze są ${ }^{3}$. Procedury awaryjne mają charakter pomocniczy - powinny być jednak stosowane wyłącznie w sytuacji, kiedy niemożliwe stanie się uchwalenie ustawy budżetowej w „zasadniczej” procedurze.

$1 \quad$ Konstytucja Rzeczypospolitej Polskiej z dnia 2 kwietnia 1997 r. (Dz.U. z 1997 nr 78 poz. 483 ze zm.), dalej: Konstytucja RP.

2 M. Zubik, Ustawa o prowizorium budżetowym w świetle Konstytucji RP, „Przegląd Sejmowy” 1999, nr 3, s. 20.

3 G. Kuca, Procedura budżetowa we współczesnym prawie konstytucyjnym. Analiza porównawcza na przykładzie państw UE, Warszawa 2018, s. 281. 
Celem niniejszego opracowania jest przedstawienie procedur awaryjnych występujących w Polsce i innych państwach Unii Europejskiej oraz próba odpowiedzi na pytanie, czy Konstytucja RP w sposób dostateczny normuje przedmiotową kwestię. W tym celu analizuję przepisy obecnej polskiej ustawy zasadniczej oraz konstytucji wybranych państw Unii Europejskiej. Całość kończy podsumowanie i przedstawienie wniosków de lege ferenda.

\section{Rodzaje procedur awaryjnych w europejskich porządkach prawnych}

Najbardziej znaną budżetową procedurą awaryjną jest prorogacja budżetowa, czyli automatyczne przedłużenie mocy obowiązywania budżetu. Tego rodzaju procedura została zastosowana w dwunastu państwach Unii Europejskiej (Bułgaria, Czechy, Estonia, Hiszpania, Holandia, Portugalia, Rumunia, Słowacja, Słowenia, Węgry, Litwa, Łotwa) ${ }^{4}$. W przypadku, kiedy ustawa budżetowa nie weszła w życie wraz z rozpoczęciem roku budżetowego, następuje automatyczne przedłużenie mocy obowiązującej dotychczasowego budżetu - rząd uprawniony jest do prowadzenia gospodarki finansowej na podstawie ostatnio obowiązującej ustawy budżetowej.

Prorogacja jest procedurą, która zapobiega powstaniu „próżni budżetowej”. Jej zastosowanie pośrednio stanowi również gwarancję, że gospodarka finansowa państwa zawsze będzie prowadzona na podstawie aktu, który został autoryzowany przez parlament. Przeciwko jej stosowaniu może przemawiać jednak naruszenie zasady roczności budżetu oraz niedopasowanie postanowień istniejących w poprzedniej ustawie budżetowej do aktualnych realiów.

Powyższe rozwiązanie znalazło uznanie w oczach litewskiego ustrojodawcy, jednakże z pewnymi ograniczeniami. Zgodnie z art. 132 Konstytucji Litwy ${ }^{5}$ „Jeżeli ustawa budżetowa państwa nie zostanie uchwalona

\footnotetext{
Tamże, s. 281.

Konstytucja Republiki Litewskiej z dnia 25 października 1992 ze zm., tłum.

H. Wisner, tekst dostępny na stronie: http://biblioteka.sejm.gov.pl/wp-

content/uploads/2016/01/Litwa_pol_010711.pdf, (dostęp: 12.12.2018 r.).
} 
w terminie, comiesięczne wydatki od początku roku budżetowego nie mogą być wyższe niż $1 / 12$ wydatków budżetu roku poprzedniego.” Instytucja prorogacji budżetowej została również unormowana w § 118 Konstytucji Estonii ${ }^{6}$. W przypadku nieuchwalenia budżetu przez Riigikogu przed początkiem roku budżetowego zezwala się na dokonywanie wydatków miesięcznych w wysokości 1/12 części wydatków budżetu roku poprzedniego. Jednakże jeżeli budżet państwa nie zostanie uchwalony w ciągu dwóch miesięcy od początku roku budżetowego, Prezydent Estonii zarządza przedterminowe wybory. Z kolei art. 148 Konstytucji Słowenii $^{7}$ wskazuje, że nieprzyjęcie budżetu do dnia, od którego powinien być realizowany, implikuje tymczasową realizację wydatków na podstawie budżetu poprzednio obowiązującego. Instytucja prorogacji nie została natomiast wprowadzona do polskiego porządku prawnego.

Kolejną stosowaną w europejskich porządkach prawnych procedurą awaryjną jest prowizorium budżetowe, które stanowi zastępczą formę dla właściwej ustawy budżetowej, jednakże w krótszej perspektywie czasowej, na ogół ściśle nieokreślonej. Zazwyczaj uchwalanie prowizorium budżetowego opiera się o odpowiednie stosowanie przepisów właściwych dla zasadniczej procedury budżetowej ${ }^{8}$, co daje gwarancję jakości ustawy o prowizorium budżetowym, ponadto przyjęcie formy ustawowej gwarantuje parlamentowi prawo do określania wydatków i dochodów ${ }^{9}$.

Mechanizm ten występuje w polskim porządku prawnym, do którego został wprowadzony na podstawie przepisów konstytucyjnych (art. 219 ust. 3 Konstytucji RP). Ponadto tego rodzaju procedura awaryjna występuje w konstytucjach Finlandii (art. 85) oraz Danii (art. 45 ust. 2). Ciekawe w tym kontekście wydaje się rozwiązanie z Konstytucji Włoch, która nie posługuje się co prawa terminem „prowizorium budżetowym”, lecz

6 Konstytucja Republiki Estońskiej z 28 czerwca 1992 r. z późn. zm,, tłum. Aarne Puu, tekst dostępny na stronie: http://biblioteka.sejm.gov.pl/wpcontent/uploads/2015/10/Estonia_pol_010811.pdf, (dostęp: 12.12.2018 r.).

7 Konstytucja Republiki Słowenii z dnia 23 grudnia 1991 r. z późn. zm., tłum P. Winczorek, tekst dostępny na stronie: http://biblioteka.sejm.gov.pl/wp-content/uploads/ 2016/11/Slowenia_pol_010711.pdf (dostęp: 12.12.2018 r.).

$8 \quad$ G. Kuca, Procedura budżetowa we wspótczesnym prawie konstytucyjnym.., s. 285.

$9 \quad$ M. Zubik, Ustawa o prowizorium budżetowym w świetle Konstytucji RP..., s. 21. 
normuje tymczasowe wykonanie budżetu, które jest dopuszczalne tylko w drodze ustawy i na okresy nieprzekraczające łącznie czterech miesięcy.

Warte przytoczenia jest również rozwiązanie austriackie, które ma charakter procedury awaryjnej. Konstytucja Austrii w art. 51 a wskazuje, że w sytuacji, w której Rząd Federalny nie złoży w odpowiednim czasie projektu ramowej federalnej ustawy budżetowej lub federalnej ustawy budżetowej, jej projekt mogą złożyć także członkowie Rady Narodowej. Rozwiązanie to ma na celu zainicjowanie procedowania budżetu przez parlament w sytuacji, w której rząd nie wypełni swojego obowiązku i nie złoży projektu ustawy budżetowej w odpowiednim terminie. Innymi słowy, Rada Narodowa niejako zastępuje Rząd Federalny jako inicjatora budżetowej ścieżki legislacyjnej w sytuacji określonej w art. 51a Konstytucji Austrii. Rozwiązanie to stanowi zatem gwarancję wszczęcia parlamentarnego etapu prac nad projektem ustawy budżetowej.

Procedury awaryjne można podzielić więc na dwa rodzaje - zastępcze oraz klasyczne. Do pierwszego rodzaju należy zaliczyć przytoczone rozwiązanie austriackie, do drugiego wspomnianą prorogację budżetową, prowizorium budżetowe czy prowadzenie gospodarki finansowej państwa na podstawie projektu ustawy budżetowej (projektu ustawy o prowizorium budżetowym). Zadaniem obydwu rodzajów procedur jest uniemożliwienie powstania „próżni budżetowej” i doprowadzenie do zapewnienia podstawy do prowadzenia gospodarki finansowej, jednakże stosowane są na różnym etapie ścieżki legislacyjnej dotyczącej ustawy budżetowej. Zadaniem procedur zastępczych jest zainicjowanie postępowania parlamentarnego w ramach procedury budżetowej z powodu zaniechań „właściwego" inicjatora postępowania ustawodawczego. Procedury klasyczne z kolei chronią przed powstaniem „próżni budżetowej”, zarówno ze względu na niezainicjowanie odpowiedniego postepowania i niezłożenie żadnego projektu ustawy budżetowej lub ustawy o prowizorium budżetowym (prorogacja), jak i przed innymi sytuacjami, ze względu na które zakończenie procedury budżetowej w wymaganym terminie stało się niemożliwe. Stosowane są również na innym etapie procedury budżetowej. 


\section{Procedury awaryjne w polskim porządku prawnym}

\subsection{Ustawa o prowizorium budżetowym}

Konstytucja RP nie przewiduje procedur zastępczych w ogóle, natomiast sposób ujęcia dwóch procedur klasycznych nie pozostaje do końca trafny. Należy tu przytoczyć art. 219 ust. 3 Konstytucji RP, który wprowadza do porządku polskiego prawnego ustawę o prowizorium, oraz art. 219 ust. 4 Konstytucji RP, wskazujący, że jeżeli ustawa budżetowa albo ustawa o prowizorium budżetowym nie weszły w życie w dniu rozpoczęcia roku budżetowego, Rada Ministrów prowadzi gospodarkę finansową na podstawie przedłożonego projektu ustawy. W polskim porządku prawnym nie jest natomiast stosowana instytucja prorogacji budżetowej, czyli przedłużenie obowiązywania ustaleń budżetowych z poprzedniego okresu.

Prowizorium budżetowe stanowi pewnego rodzaju krótkotrwałą alternatywę dla ustawy budżetowej. Jest to de facto tymczasowy budżet państwa, zaprojektowany przez Radę Ministrów, następnie przyjęty przez parlament. Jego zakres przedmiotowy jest zbieżny z zakresem ustawy budżetowej ${ }^{10}$, różni się natomiast zakresem czasowym. Ustawa o prowizorium budżetowym sama określa ramy swojego obowiązywania. Po ich upływie, a także na skutek uchwalenia ustawy budżetowej, traci moc ${ }^{11}$. Uchwalenie przedmiotowej instytucji nie zwalnia Rady Ministrów z obowiązku przedstawienia projektu budżetu państwa obejmującego cały rok budżetowy, ponieważ, jak już wskazano powyżej, jest to rozwiązanie wyłącznie tymczasowe. Prowizorium budżetowe może być stosowane jedynie w „wyjątkowych przypadkach”. Ani Konstytucja RP, ani ustawa nie definiują powyższego terminu. Według propozycji doktryny pojęcie „wyjątkowych przypadków” należy rozumieć jako jednorazowe, faktyczne zdarzenie, którego nie można było wcześniej przewidzieć stanowiące realną i bezpośrednią przyczynę nieuchwalenia ustawy budżetowej

10 W. Sokolewicz, Komentarz do art. 219 [w:] L. Garlicki (red.), Konstytucja Rzeczypospolitej Polskiej. Komentarz, Warszawa 2005, s. 48.

11 B. Banaszak, Komentarz do art. 219 [w:] Konstytucja RP. Komentarz, System Informacji Prawnej „Legalis” nb. 12. 
w terminie i jednocześnie niepowodujące przeszkód w uchwaleniu ustawy o prowizorium budżetowym ${ }^{12}$. Ocena przesłanek „wyjątkowych wypadków” należy każdorazowo do Rady Ministrów. Jednakże, jak słusznie, zauważa C. Kosikowski, Rada Ministrów powinna w uzasadnieniu wskazać przyczynę sięgnięcia po tę procedurę awaryjną ${ }^{13}$.

Ustrojodawca nakazuje „odpowiednie” stosowanie przepisów dotyczące projektu ustawy budżetowej wobec ustawy o prowizorium budżetowym, a zatem nie utożsamia tych aktów ${ }^{14}$. Chodzi tu o całokształt przepisów normujących powyższą materię, nie tylko tych umieszczonych w Konstytucji $\mathrm{RP}^{15}$ - do obu projektów należy stosować te same zasady ich opracowania i ten sam tryb pracy nad nimi w parlamencie. Ustawa o prowizorium budżetowym nie może odbiegać w istotnym stopniu od standardów jawności i szczegółowości ustawy budżetowej. Projekt ustawy o prowizorium budżetowym powinien spełniać formalne warunki, które stawiane są ustawie budżetowej. Tym samym powinien zawierać uzasadnienie z odpowiednim uwzględnieniem wymogów z art. 142 ustawy o finansach publicznych ${ }^{16} \mathrm{w}$ zakresie, w jakim nie jest to wyłączone na mocy pozostałych przepisów - chociażby z art. 144 ust. 2 u.f.p.

Jak już zaznaczono, ustrojodawca nie zdecydował się na zakreślenie ram czasowych ustawy o prowizorium budżetowym, dlatego też okres, na jaki będzie obowiązywać, powinien zostać każdorazowo unormowany w niej samej. Istotą przedmiotowej procedury jest fakt, że trwa „krócej niż rok”. Ustrojodawca nie zastosował więc rozwiązań włoskich ograniczających obowiązywanie tymczasowego budżetu do czterech miesięcy ${ }^{17}$. Jest to słuszne rozwiązanie. Ramy czasowe właściwe dla prowizorium budże-

\footnotetext{
W. Sokolewicz, Komentarz do art. 219..., s. 48.

13 C. Kosikowski, Finanse publiczne w świetle Konstytucji RP oraz orzecznictwa Trybunału Konstytucyjnego (na tle porównawczym), Warszawa 2004, s. 126.

14 C. Kosikowski, Zasady ustroju społecznego i gospodarczego w procesie stosowania Konstytucji, Warszawa 2005 s. 179.

15 M. Zubik, Budżet państwa w polskim prawie konstytucyjnym, Warszawa 2001, s. 259.

16 Ustawa z dnia 27 sierpnia o finansach publicznych (Dz.U. z 2017r. poz. 2077), dalej jako u.f.p.

17 Konstytucja Republiki Włoskiej z dnia 27 grudnia 1947 r. ze zm., tłum. Z. Witkowski, tekst dostępny na stronie: http://biblioteka.sejm.gov.pl/wp-content/uploads/2016/11/ Wlochy_pol_010711.pdf, (dostęp: 12.12.2018 r.).
} 
towego powinny być każdorazowo rozpatrywane pod kątem przyczyn, dla których sięgnięto po tę procedurę.

Teoretycznie możliwie jest uchwalenie jej na okres przekraczający 11 miesięcy, jednakże takie działanie należy uznać za niezgodne z Konstytucją RP i mające na celu obejście jej unormowań ${ }^{18}$. Z treści Konstytucji RP jasno bowiem wynika, że prowizorium budżetowe ma charakter subsydiarny i stosowane jest wyłącznie w przypadku braku możliwości uchwalenia ustawy budżetowej. Trudno byłoby usprawiedliwić przedłożenie przez Radę Ministrów projektu ustawy o prowizorium budżetowym np. na 11 miesięcy.

$\mathrm{Z}$ drugiej jednak strony, warto też zauważyć na regulację z art. 144 ust.3 u.f.p, zgodnie z którą Rada Ministrów zobligowana jest do przedstawienia Sejmowi projektu ustawy budżetowej nie później niż na 3 miesiące przed zakończeniem okresu obowiązywania ustawy o prowizorium budżetowym. Okres obowiązywania przedmiotowej procedury nie może być więc zbyt krótki. Przedłożenie przez Radę Ministrów projektu prowizorium budżetowego, którego ramy czasowe wyznaczone zostałyby przykładowo na dwa tygodnie, nie wydaje racjonalne. Egzekutywa byłaby bowiem zobligowana, na podstawie wyżej wspomnianego przepisu, do złożenia w niewielkim odstępie czasu projektu „właściwej” ustawy budżetowej, co w zasadzie doprowadziłby do „skonsumowania” projektu prowizorium budżetowego, ponieważ nie wydaje się prawdopodobne, aby w tak krótkim okresie ten ostatni wszedł w życie. Ponadto podawałoby w wątpliwość istnienie „wyjątkowych przypadków”. Trudno byłoby racjonalnie wytłumaczyć wagę przyczyny, dla której zastosowano prowizorium budżetowe, kiedy powody jego zastosowania ustąpiłyby w niedługiej perspektywie czasowej.

Historia prowizorium budżetowego w Polsce sięga okresu międzywojennego. Możliwość uchwalania przedmiotowej instytucji wprowadzała chociażby „nowela sierpniowa” ${ }^{\text {}}{ }^{\text {. Z }}$ Z przedmiotowej procedury skorzystano już w 1926 r., kiedy to nie udało się uchwalić całościowego budże-

\footnotetext{
M. Zubik, Budżet państwa w polskim prawie konstytucyjnym..., s. 268.

19 Zob. art. 3 ustawy z dnia 2 sierpnia 1926 r. zmieniającej i uzupełniającej Konstytucję Rzeczypospolitej z 17 marca 1921 r. (Dz.U. z 1926 Nr 78, poz.442).
} 
tu, a gospodarka finansowa była w tym roku oparta na pięciu prowizoriach budżetowych ${ }^{20} \mathrm{Z}$ reguły prowizoria budżetowe przyjmowane w międzywojennym okresie obowiązywały nie dłużej niż kwartał ${ }^{21}$. W Polsce powojennej od 1944 do 1947 r. uchwalane były jedynie prowizoria budżetowe, a pierwszy budżet uchwalony został, tak jak przewidywała to tzw. mała Konstytucja, w formie ustawy dopiero 1 lipca $1947 \mathrm{r}^{22}$. Obecnie prowizorium budżetowe, ze względu na niechęć rządu do opracowywania odrębnego projektu budżetu państwa i poddanie go pod ocenę parlamentu, stosowane jest rzadko ${ }^{23}$. Od 1989 r. ustawa o prowizorium budżetowym obowiązywała w Polsce tylko raz - w $1992 \mathrm{r}^{24}$. - i został przyjęta w związku ze skróceniem skrócenia kadencji Sejmu kontraktowego.

\subsection{Brak wejścia w życie ustawy budżetowej (ustawy o prowizorium budżetowym) przed rozpoczęciem roku budżetowego}

Przepisy Konstytucji RP przewidują procedurę rezerwową na wypadek niewejścia w życie wraz z rozpoczęciem roku budżetowego ustawy budżetowej (ustawy o prowizorium budżetowym). Zgodnie z art. 219 ust. 4 Konstytucji RP Rada Ministrów prowadzi gospodarkę finansową na podstawie przedłożonego projektu ustawy, przy czym należy zaznaczyć, że warunkiem wejścia w życia każdej ustawy jest jej ogłoszenie (art. 88 Konstytucji RP).

W Polsce jest to najczęściej stosowana procedura awaryjna. Warunkiem skorzystania z procedury z art. 219 ust 4 Konstytucji RP jest przedłożenie przez Radę Ministrów projektu ustawy budżetowej lub ustawy o prowizorium budżetowym oraz niewejście w życie wyżej wskazanych

20 A. Kaczmarek, Ewolucja prawa budżetowego, „Studia BAS” 2010, nr 3, s. 20.

21 T. Augustyniak-Górna, Budżet państwa, ustawa budżetowa, ustawa o prowizorium budżetowym, Informacja BSiE $\mathrm{nr} 1158$, s. 6, tekst dostępny na stronie: http://biurose.sejm.gov.pl/teksty_pdf_05/i-1158.pdf, (dostęp: 28.02.2019 r.).

22 A. Kaczmarek, Ewolucja prawa budżetowego..., s. 21.

23 G. Kuca, Procedura budżetowa we współczesnym prawie konstytucyjnym..., s. 288.

24 Zob. ustawa z dnia 25 stycznia 1992 r. o prowizorium budżetowym na okres od dnia 1 stycznia do dnia 31 marca 1992 r. (Dz.U. z 1992 nr 19 poz. 77). 
projektów. Jak słusznie zauważa M. Zubik, nie jest konieczne, aby tego rodzaju projekt był złożony na trzy miesiące przed rozpoczęciem roku budżetowego, o ile zachodzą „wyjątkowe wypadki” z art. 222 Konstytucji $\mathrm{RP}^{25}$. Norma z art. 219 ust. 4 Konstytucji RP ma charakter wyjątku - nadaje bowiem moc obowiązującą projektowi ustawy, mimo że projekt nie przeszedł całej ścieżki legislacyjnej ${ }^{26}$.

Regulacja z art. 219 ust 4 Konstytucji RP ma zastosowanie w przypadku, w którym do laski marszałkowskiej złożony został projekt ustawy budżetowej lub ustawy o prowizorium budżetowym, jednakże nie został on uchwalony przed rozpoczęciem roku budżetowego przez parlament, Prezydent nie podpisał ustawy, ustawa badana jest przez Trybunał Konstytucyj$n y^{27}$. Zastosowanie powyższej procedury nie wpływa jednak na okres obowiązywania ustawy budżetowej - ta bowiem wchodzi wówczas w życie z mocą wsteczną. W tym wypadku retroakcja jest dopuszczalna, a nawet konieczna, ponieważ rok budżetowy zawsze obowiązuje od 1 stycznia $^{28}$.

Projekt ustawy budżetowej lub ustawy o prowizorium budżetowym powinien być podstawą prowadzenia gospodarki w możliwie jak najkrótszym okresie - nie jest bowiem aktem, który otrzymał legitymizację parlamentu.

Co istotne, żadna ze wskazanych awaryjnych procedur budżetowych - ani ustawa o prowizorium budżetowym, ani mechanizm z art. 219 ust. 4 Konstytucji RP - nie chroni przed powstaniem „próżni budżetowej”. Przyjęte w Polsce rozwiązania zakładają bowiem, że rząd spełni nałożony nań obowiązek i przedłoży projekt ustawy budżetowej. Konstytucja RP, odmiennie niż Konstytucja Austrii, nie przewiduje bowiem mechanizmów, które umożliwiałyby zastępcze zrealizowanie tegoż obowiązku przez inny organ. Ustrojodawca zakłada więc, że Rada Ministrów będzie działała zgodnie z przepisami.

Tymczasem nieprzedłożenie projektu ustawy budżetowej przed rozpoczęciem roku budżetowego spowoduje de facto paraliż państwa. Sytua-

\footnotetext{
M. Zubik, Budżet państwa w polskim prawie konstytucyjnym..., s. 270.

Tamże, s. 271.

Tamże, s. 269.

C. Kosikowski, Odmienności w tworzeniu ustawy budżetowej, „Przegląd Sejmowy” 1998, nr 4, s. 19.
} 
cja taka wydaje się co prawda mało prawdopodobna, ale nie niemożliwa. Jak wskazuje C. Kosikowski ${ }^{29}$, niewypełnienie przedmiotowego obowiązku powinno pociągać za sobą kategoryczną dymisję Rady Ministrów, M. Zubik z kolei przedstawia nieznacznie łagodniejsze stanowisko ${ }^{30}$. Jednakże usunięcie Rady Ministrów, jakkolwiek skompromitowanej, przez niespełnienie omawianego obowiązku nie doprowadzi do rozwiązania istoty problemu. Państwo pozostawałoby bez budżetu, przez co nie mogłoby funkcjonować we właściwy sposób. Dymisja Rady Ministrów doprowadziłaby do sytuacji, w której państwo nie posiadałoby zarówno budżetu, jak i organu, który mógłby właściwe postępowanie zainicjować.

Wyżej opisany przypadek wydaje się trudny do wyobrażenia. Jednakże trzeba zwrócić uwagę, że jest pewnym curiosum występowanie dwóch procedur bezpieczeństwa, które de facto nie chronią w pełni skutecznie przed powstaniem „próżni budżetowej”. Ta natomiast nie musi powstać tylko przez przykład opisany powyżej, ale również przez odrzucenie w całości projektu ustawy budżetowej przez Sejm oraz zakwestionowanie jej konstytucyjności przez Trybunał Konstytucyjny. Rodzi się pytanie, czy procedura awaryjna unormowana w art. 219 ust. 4 Konstytucji RP będzie miała zastosowanie w dwóch powyższych przypadkach.

Wydaje się, że w takich sytuacjach należałoby przyznać pierwszeństwo wykładni funkcjonalnej art. 219 ust. 4 Konstytucji RP, a więc zapewnieniu podstawy do prowadzenia gospodarki finansowej państwa, inne podejście doprowadziłoby bowiem do paraliżu państwa. Z drugiej jednak strony, powstałaby sytuacja, w której podstawą prowadzenia polityki finansowej państwa byłby projekt ustawy, który spotkał się ze zdecydowaną kontestacją parlamentu lub którego przepisy w całości zostały zakwestionowane przez Trybunał Konstytucyjny. Dlatego też przyjęty mechanizm z art. 219 ust. 4 Konstytucji RP nie wydaje się odpowiednim rozwiązaniem. Nie zapewnia bowiem pełnej ochrony przed powstaniem „próżni budżetowej”, a wręcz może prowadzić do sytuacji, której gospodarka finansowa byłaby prowadzona na podstawie niekonstytucyjnego

29 C. Kosikowski, Finanse publiczne w świetle Konstytucji RP oraz orzecznictwa Trybunału Konstytucyjnego (na tle porównawczym)..., s. 125.

30 M. Zubik, Budżet państwa w polskim prawie konstytucyjnym..., s. 280. 
aktu lub takiego, który spotkał się ze zdecydowanym sprzeciwem parlamentu. Ponadto, jak słusznie wskazuje A. Borodo, mechanizm z art. 219 ust. 4 Konstytucji RP w istotny sposób podważa uprawnienia budżetowe parlamentu $^{31}$.

\section{Ocena polskich uregulowań}

Powyższe rozwiązania wskazują, że do polskiego porządku prawnego wprowadzono dwie równorzędne sobie procedury awaryjne, które stanowią podstawę prowadzenie gospodarki w możliwie jak najkrótszym okresie. W porównaniu z ustawą budżetową są jednak rozwiązaniami ułomnymi, gdyż nie wykazują wszystkich jej wymaganych standardów i cech $^{32}$. Zastosowanie procedury, o której mowa w art. 219 ust. 4 Konstytucji RP, nie jest uzależnione od pierwotnego zastosowania mechanizmu z art. 219 ust. 3 Konstytucji RP. Jednakże w przypadku nieuchwalenia ustawy o prowizorium budżetowym przed rozpoczęciem roku budżetowego, to jego projekt będzie podstawą do prowadzenia gospodarki finansowej państwa.

Przyjęte $\mathrm{w}$ polskim porządku prawnym budżetowe procedury awaryjne stosuje się w innych sytuacjach. Warunkiem zastosowania ustawy o prowizorium budżetowym jest wystąpienie „wyjątkowych przypadków”, ze względu na które niemożliwe jest wniesienie projektu ustawy budżetowej. Jak już zaznaczono, ustrojodawca nie określił terminu „wyjątkowych przypadków”, każdorazowa ich ocena uzależniona pozostaje więc od konkretnej sytuacji. Jednakże powinny być to okoliczności o charakterze zewnętrznym, a nie leżące po stronie Rady Ministrów. Ta ma bowiem zapewniony odpowiedni aparat do przygotowania projektu ustawy budżetowej, sama procedura jest rozłożona w czasie, więc nieprzygotowanie projektu ustawy budżetowej wyłącznie ze względu na czynniki wewnętrzne nie powinno być traktowane jako zaistnienie „wyjątkowych przypadków”. Przygotowanie ustawy budżetowej obejmującej cały rok

\footnotetext{
A. Borodo, Prawo finansowe zarys ogólny, Toruń 2014, s. 60.

32 T. Dębowska-Romanowska, Prawo finansowe. Część konstytucyjna wraz z częściq ogólnq, Warszawa 2009, s. 226.
} 
budżetowy i złożenie jej we właściwym terminie należy bowiem do obowiązków Rady Ministrów i ta powinna podjąć wszelkie działania, aby tę powinność spełnić. Wydaje się również, że „wyjątkowym przypadkiem” nie są wybory parlamentarne, które wiążą się z pewną cyklicznością, chyba ze ich przeprowadzenie nastąpiło w efekcie skrócenia kadencji Sejmu.

Procedura, która została uregulowana w art. 219 ust. 4 Konstytucji $\mathrm{RP}$, jest natomiast stosowana w sytuacjach, w których projekt ustawy budżetowej lub ustawy o prowizorium budżetowym został już złożony do laski marszałkowskiej, jednak nie wszedł w życie z powodu przedłużających się prac parlamentarnych, został odrzucony w całości, a Rada Ministrów nie zdążyła wnieść kolejnego projektu, lub badana jest jego konstytucyjność.

Podstawy stosowania dwóch równorzędnych procedur awaryjnych przewidzianych przez polskiego ustrojodawcę są więc odmienne. Wspólne jest jednak to, że, mają one charakter subsydiarny względem „właściwej” procedury budżetowej i stosowanie nie powinno stać się zasadą.

Jak już wskazano, do polskiego porządku prawnego nie wprowadzono natomiast instytucji prorogacji budżetowej, mimo iż jest to najczęściej stosowane rozwiązanie na świecie ${ }^{33}$. Owszem, trzeba uwzględnić fakt, że podstawą gospodarki finansowej byłby akt, który niekoniecznie zostałby dopasowany do aktualnych realiów, jednak należy pamiętać, że skorzystanie z tej instytucji powinno mieć charakter wyłącznie pomocniczy i nie być nadużywane. Ponadto trzeba też zwrócić uwagę, że występowanie wydatków stałych, które muszą zostać uwzględnione w budżecie państwa, powoduje, że kolejne ustawy budżetowe nie różnią się od siebie w sposób diametralny.

Co więcej, wprowadzenie do polskiego porządku prawnego instytucji prorogacji budżetowej wzmacniałoby pozycję parlamentu w procedurze budżetowej. Niemożliwa stałaby się bowiem sytuacja, w której podstawą gospodarki budżetowej byłby akt, który nie uzyskał autoryzacji parlamentu.

Rozwiązania zawarte w Konstytucji RP uzależniają zastosowania procedur awaryjnych od działania rządu. Przyznanie wyłącznej inicjatywy

33 G. Kuca, Procedura budżetowa we współczesnym prawie konstytucyjnym..., s. 288. 
ustawodawczej w zakresie ustawy budżetowej oraz ustawy o prowizorium budżetowym Radzie Ministrów uniemożliwia przedstawienie projektu przez inny organ. W przypadku, w którym rząd nie podejmie jakichkolwiek działań w powyższym zakresie, powstanie „próżnia budżetowa”, czyli sytuacja, w której nie ma budżetu państwa oraz żadna z przewidzianych przepisami prawa procedur awaryjnych pozostaje bezskuteczna.

W tym miejscu trzeba jeszcze zwrócić uwagę na jedno rozwiązanie, które przewidział polski ustrojodawca - mianowicie skrócenie kadencji Sejmu w razie nieprzyjęcia ustawy budżetowej. Zgodnie z art. 225 Konstytucji RP jeżeli w ciągu 4 miesięcy od dnia przedłożenia Sejmowi projektu ustawy budżetowej nie zostanie ona przedstawiona Prezydentowi Rzeczypospolitej do podpisu, Prezydent Rzeczypospolitej może w ciągu 14 dni zarządzić skrócenie kadencji Sejmu. Omawiana regulacja stanowi wyjątek od ram czasowych kadencji Sejmu, która zgodnie z art. 98 Konstytucji RP jest czteroletnia. Kompetencja ma charakter fakultatywny, Prezydent może, ale nie musi z niej skorzystać.

Podobne regulacje występują w Estonii. Jednak trudno uznać obecne rozwiązania za optymalne. Jak wskazuje A. Borodo: „wydaje się, że uprawnienie do skrócenia kadencji Sejmu nie jest właściwym rozwiązaniem (...). W wyniku zastosowania tego rozwiązania powstaje sytuacja, że budżetu (jako aktu parlamentu) nie ma, nie ma też organu, który mógł-

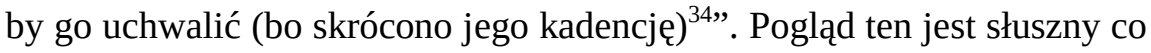
do zasady. Wykładnia art. 225 Konstytucji RP jasno wskazuje, że Prezydent RP jest uprawniony do skrócenia kadencji Sejmu, co pociąga za sobą automatyczne skrócenie Senatu. Jednakże parlament jest jeszcze władny do przyjęcia aktu budżetowego do czasu zarządzonych wyborów. Jak wskazuje W. Miemiec, „skrócona postanowieniem Prezydenta kadencja Sejmu i Senatu nie ulega natychmiastowemu przerwaniu, lecz trwa do dnia poprzedzającego dzień zebrania się na pierwszym posiedzeniu danej izby następnej kadencji Skorzystanie przez Prezydenta z prerogatywy skrócenia kadencji izb nie pozbawia zatem parlamentu kompetencji do zakończenia prac ustawodawczych nad projektem i ustawą budżetową.

34 A. Borodo, Współczesne problemy prawne budżetu państwowego, Toruń 2014, s. 149. 
Parlament może uchwalić ustawę budżetową w każdym późniejszym terminie, a Prezydent może taką ustawę podpisać albo też wystąpić z wnioskiem do Trybunału Konstytucyjnego o zbadanie jej zgodności z Konsty-

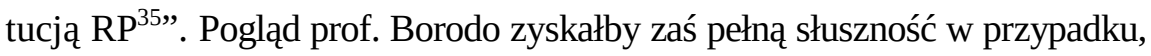
kiedy Prezydent RP posiadałby prawo rozwiązania parlamentu, jednakże ta instytucja nie jest znana współczesnej Konstytucji RP. Prawdą jest natomiast, że skorzystanie przez Prezydenta RP z uprawnienia, o którym mowa w art. 225 Konstytucji RP, może wywołać liczne komplikacje i w konsekwencji przyczynić się do powstania chaosu prawnego i politycznego.

Warto w tym miejscu również zaznaczyć, że art. 225 Konstytucji RP wskazuje, że Prezydent jest uprawniony do skrócenia kadencji Sejmu, jeżeli w ciągu 4 miesięcy od dnia przedłożenia Sejmowi projektu ustawy budżetowej nie zostanie mu przedstawiona do podpisu. Przy czym powyższy czteromiesięczny termin należy zawsze liczyć, rozpoczynając od faktycznego terminu przedłożenia projektu ustawy budżetowej ${ }^{36}$.

Konstrukcja tego przepisu jest niedoskonała, bowiem i w tym przypadku ustrojodawca zakłada spełnienie obowiązku zainicjowania procedury budżetowej przez Radę Ministrów. W przypadku niewypełnienia tejże powinności zastosowanie przez Prezydenta uprawnienia z art. 225 Konstytucji RP mogłoby budzić wątpliwości.

\section{Wnioski i postulaty de lege ferenda}

Konstytucja RP sporo uwagi poświęca zagadnieniom budżetu państwa i fakt ten należy ocenić pozytywnie. Jednakże w wielu miejscach jej unormowania są dalekie od doskonałości - głównie chodzi tu o niewystarczające ugruntowanie procedur awaryjnych. Mimo że polski ustrojodawca przewidział dwie takie procedury, to żadna z nich nie daje pełnej gwarancji zabezpieczenia przed sytuacją braku budżetu.

35 W. Miemiec W., Skrócenie kadencji sejmu w świetle art. 225 Konstytucji RP, http://www.repozytorium.uni.wroc.pl/Content/71657/06_Wies\%C5\%82awa_Miemiec. pdf (dostęp: 28.12.2018r.).

36 W. Miemiec, K. Sawicka, Komentarz do art. 225 [w:] M. Safjan, L. Bosek (red.), Konstytucja RP. Komentarz, System Informacji Prawnej „Legalis”, nb. 26. 
Dlatego też wartym rozważenia wydaje się propozycja zastąpienia mechanizmu z art. 219 ust. 4 Konstytucji RP instytucją prorogacji budżetowej, a więc automatycznego przedłużenia mocy prawnej dotychczasowego budżetu. Wprowadzenie tego narzędzia niewątpliwe wzmocniłby pozycję parlamentu w procesie budżetowym, ponieważ gospodarka finansowa państwa zawsze oparta zostałaby na akcie, który został przez legislatywę autoryzowany byłby właściwie przeanalizowany. Prorogacja budżetowa skuteczniej przeciwdziałałaby również zaistnieniu „próżni budżetowej” bez względu na przyczynę jej powstania.

Innym sposobem zabezpieczenia przed powstaniem powyższego zjawiska byłoby unormowanie w polskim porządku prawnym procedury zastępczej, podobnej do tej występującej w Konstytucji Austrii. Parlament lub jedna z jego izb mógłby inicjować postępowanie ustawodawcze w sytuacjach, kiedy nie uczyni tego we właściwy sposób Rada Ministrów. Rozwiązanie to miałoby zapewne charakter prewencyjny - stanowiłoby pewnego rodzaju zagrożenie dla rządu utraty znacznego wpływu na kształt przyszłej ustawy budżetowej. Trzeba jednak mieć na uwadze fakt, że skorzystanie z procedury zastępczej byłoby wysoce problematyczne nie wydaje się bowiem, że parlament posiada odpowiedni aparat urzędniczy, który byłby w stanie we właściwy sposób opracować projekt ustawy budżetowej. Ponadto, zastosowanie procedury zastępczej następowałoby w wyniku niezainicjowania parlamentarnego etapu procedury budżetowej przez rząd, co oznacza, że parlament zacząłby opracowywanie projektu ustawy budżetowej po 30 września. Nie wydaje się, że możliwym byłoby odpowiednie przygotowanie tak skomplikowanego i obszernego aktu oraz uchwalenie go przed rozpoczęciem roku budżetowego. Co znamienne, rozwiązanie austriackie nie zostało ani razu wykorzystane w praktyce ${ }^{37}$.

Natomiast wprowadzenie do polskiego porządku prawnego prowizorium budżetowego należy ocenić pozytywnie. Instytucja ta bowiem może być stosowana w sytuacjach nadzwyczajnych, kiedy opracowanie całorocznego budżetu jest nadmierne utrudnione lub wręcz niemożliwe.

37 G. Kuca, Procedura budżetowa we współczesnym prawie konstytucyjnym..., s. 288. 
Budżetowe procedury awaryjne...

\section{Bibliografia:}

Augustyniak-Górna T. Budżet państwa, ustawa budżetowa, ustawa o prowizorium budżetowym, Informacja $\mathrm{BSiE} \mathrm{nr} 1158$, s. 6, tekst dostępny na stronie: http://biurose.sejm.gov.pl/teksty_pdf_05/i-1158.pdf, (dostęp: 28.02.2019r.).

Banaszak B., Komentarz do art. 219 [w:] Konstytucja RP. Komentarz, System Informacji Prawnej „Legalis”.

Borodo A., Prawo finansowe. Zarys ogólny, Toruń 2014.

Borodo A., Współczesne problemy prawne budżetu państwowego, Wydawnictwo Naukowe Uniwersytetu Mikołaja Kopernika, Toruń 2014.

Dębowska-Romanowska T., Prawo finansowe. Część konstytucyjna wraz z częściq ogólnq, C.H. Beck, Warszawa 2009.

Kaczmarek A., Ewolucja prawa budżetowego, „Studia BAS” 2010, nr 3, s. 10-24.

Kosikowski C., Finanse publiczne w świetle Konstytucji RP oraz orzecznictwa Trybunału Konstytucyjnego (na tle porównawczym), Wydawnictwo Sejmowe, Warszawa 2004.

Kosikowski C., Odmienności w tworzeniu ustawy budżetowej, „Przegląd Sejmowy” 1998, nr 4, s. 9-21.

Kosikowski C., Zasady ustroju społecznego i gospodarczego w procesie stosowania Konstytucji, Wydawnictwo Sejmowe, Warszawa 2005.

Kuca G., Procedura budżetowa we współczesnym prawie konstytucyjnym. Analiza porównawcza na przykładzie państw UE, Wolters Kluwer, Warszawa 2018.

Miemiec W., Skrócenie kadencji sejmu w świetle art. 225 Konstytucji RP, http://www.repozytorium.uni.wroc.pl/Content/71657/06_Wies\%C5\%82awa _Miemiec. pdf (dostęp: 28.12.2018r.).

Miemiec W., Sawicka K., Komentarz do art. 225 [w:] M. Safjan, L. Bosek (red.), Konstytucja RP. Komentarz, System Informacji Prawnej „Legalis”.

Sokolewicz W., Komentarz do art. 219 [w:] L. Garlicki (red.), Konstytucja Rzeczypospolitej Polskiej. Komentarz, Wydawnictwo Sejmowe, Warszawa 2005.

Zubik M., Budżet państwa w polskim prawie konstytucyjnym, Wydawnictwo Sejmowe, Warszawa 2001.

Zubik M., Ustawa o prowizorium budżetowym w świetle Konstytucji RP, „Przegląd Sejmowy” 1999, nr 3, s. 20-38. 